\title{
Mixed-species schooling behavior and protective mimicry involving coral reef fish from the genus Haemulon (Haemulidae)
}

\author{
Pedro Henrique Cipresso Pereira, João Lucas Leão Feitosa and \\ Beatrice Padovani Ferreira
}

The present study analyzed heterotypic schooling behavior and protective mimicry relationships involving species of the genus Haemulon and other coral reef fishes on coastal reefs at Tamandaré, Pernambuco State, Northeastern Brazil. The work was performed during 35 hours of direct observation using the "focal animal" method. The observed events involved 14 species of reef fish in eight different families. The phenomenon of mixed schooling appeared to be related to the large number of individuals of the genus Haemulon present in reef environments and to the tendency of individuals with limited populations to try to aggregate in schools (e.g. genus Scarus).

O presente estudo analisou o comportamento de formação de cardumes mistos e mimetismo de proteção envolvendo espécies do gênero Haemulon e demais peixes recifais nos recifes costeiros de Tamandaré, estado de Pernambuco, Nordeste do Brasil. O trabalho foi realizado utilizando observações subaquáticas e incluiu 35 horas de observação direta utilizando o método animal focal, durante as quais foram registradas associações com 14 espécies pertencentes a oito famílias diferentes. Os fenômenos registrados possivelmente estão relacionados à grande quantidade de indivíduos do gênero Haemulon presentes nos ecossistemas recifais e também à tendência de indivíduos com reduzidas populações a permanecerem em cardumes (e.g. gênero Scarus).

Key words: Grunts, Heterotypic schooling, Social mimicry, Western Atlantic.

\section{Introduction}

The aggregation of individuals is a biological phenomenon observed from the lowest life forms (bacteria) to the largest organisms (whales), and involves virtually all taxa, habitats, trophic levels, life history strategies, and many other biological characteristics (Parrish \& Edelstein-Keshet, 1999; Camazine et al., 2001).

The family Haemulidae (grunts) comprises 17 genera and about 145 species distributed throughout the world, occurring mainly in marine and estuarine environments (Lindeman \& Toxey, 2002; Nelson, 2006). The genus Haemulon is represented by 15 species distributed along the Western Atlantic and Eastern Pacific coasts, with one species being found in both regions (Rocha \& Rosa, 1999). This genus numerically dominates shallow reef communities and typical schools of up to hundreds of individuals are found over natural or artificial structures with adult, juvenile, and newly settled fish (Mateo \& Tobias, 2001; Brotto et al., 2007). They represent an excellent group for ecological studies due to its diverse ecomorphology, great abundance, and ecological and economic importance (Lindeman \& Toxey, 2002; Rocha et al., 2008).

Situations in which a single species is not abundant enough to maintain a school, the heterotypic grouping with other abundant species can occur (Ogden \& Ehrlich, 1977), such as with the highly numerous schooling haemulids. Fish typically present this kind of behavior to gain access to the defended resources of territory holders, decrease search times for patchily distributed resources, and provide increased protection from predation with species that have similar body shapes and colorations (Ehrlich \& Ehrlich, 1973; Itzkowitz, 1977; Debrot \& Myrberg, 1988; Ward et al., 2002).

Another tactic used to confound predators or to gain access to inaccessible resources is mimicry behavior, where one species closely resembles another, which has arisen many times throughout the plant and animal kingdoms (Malcolm, 1990; Moland et al., 2005). This phenomenon has been described for a wide range of reef fish species and seems to be most prevalent in the Blenniidae, Serranidae, and Apogonidae families, with members mainly mimicking species of the families

Universidade Federal de Pernambuco (UFPE), Departamento de Oceanografia, CTG. Av. Arquitetura, s/n, Cidade Universitária, 50670-901 Recife, PE, Brazil.pedrohcp2@yahoo.com.br 
Pomacentridae, Labridae, and Blenniidae (Moland et al., 2005). It is apparently more commonly expressed during the juvenile phases of these species; most mature individuals change their appearances and thus lose their mimicking characteristics as adults (Snyder, 2001; Randall, 2005).

Four main types of mimicry have been described in the literature. Batesian mimicry is characterized by a harmless palatable species mimicking an unpalatable or poisonous species in order to avoid predators (e.g. Sazima, 2002a). Müllerian mimicry is characterized by two unpalatable species that have similar color patterns and thus mutually strengthen their protection against predators. Aggressive mimicry occurs when a predator species resembles a harmless or beneficial species and thus gains more foraging opportunities by deceiving its prey (e.g. Sazima, 2002b; Moland \& Jones, 2004). Protective mimicry occurs when one species mimics another of similar color or shape in order to distract the attention of its predators (Dafni \& Diamant, 1984; Randall, 2005).

The aim of the present work was to analyze heterospecific schooling behavior involving species of the genus Haemulon and other reef fish. To clarify this subject, two questions were raised: which species join heterotypic schools of Haemulon spp. at the site evaluated in the present study? Which tactics of schooling do these species display when associated with grunts?

\section{Material and Methods}

The reef complex studied is within the limits of the "Costa dos Corais" Marine Protection Area (MPA) that encompasses $135 \mathrm{~km}$ of coastline in Pernambuco State in Northeastern Brazil. The Costa dos Corais - MPA was the first Brazilian federal conservation area that included coastal reefs and is the largest MPA in the country, encompassing an area of approximately 413,563 hectares (Maida \& Ferreira, 1997; Ferreira et al., 2001).

Observations were made while snorkeling in shallow waters or while using SCUBA in deeper areas between November 2009 and April 2010, from the early morning (8:00 am) until late afternoon $(5: 00 \mathrm{pm})$. Sample units were haphazardly chosen Haemulon schools $(\mathrm{N}=250)$ observed using the focal animal method (Altmann, 1974). Each observational session lasted from 5 to 10 minutes (totalizing 35 hours), recording which species formed mixed schools and the frequencies they interacted with Haemulon spp. The life stages of the species, their trophic categories (according to Ferreira et al., 2004), and their behavior during shoal formation were also considered. Associations involving four species from the genus Haemulon were noted: Haemulon aurolineatum, Haemulon parra, Haemulon plumieri, and Haemulon squamipinna.

\section{Results}

A total of 14 species of reef fish belonging to eight different families were observed schooling with Haemulon spp. on 99 occasions (Table 1). The most sighted species during these interactions were Lutjanus alexandrei $(20 \%$ of the total number of interactions), Pseudupeneus maculatus (19\%), Anisotremus virginicus (13\%), and Mulloidichthys martinicus (10\%). The most representative trophic guilds were mobile invertebrate feeders $(\mathrm{N}=7$ species), followed by carnivores and roving herbivores ( $\mathrm{N}=4$ species each).

The schooling grunts that were used most frequently by other reef fish were Haemulon aurolineatum and $H$. squamipinna, (73\% of the interactions each); whereas $H$. plumieri had the lowest rate use on the interactions (33\%). On $33 \%$ of the observation sessions $(\mathrm{N}=5)$ all of the Haemulon species analyzed herein were involved on the same heterotypic school (Table 1).

Two main tactics were recorded for the species joining Haemulon schools: the simple heterotypic schooling behavior and protective mimicry (Fig. 1). The former was characterized by a species that do not resemble the nuclear Haemulon species neither regarding coloration nor behavior, but still aggregates with the schools in order to gain protection by the increased number of individuals (Fig. 2). Species categorized as being on protective mimicry behavior included those who presented similar appearance with Haemulon spp. on color patterns, body shape and size. Swimming movements and postures mimicking the nuclear school were also taken into account when assigning

Table 1. Number of observed events $(\mathrm{N})$ between the genus Haemulon and other coral reef fish species. Life phase: J for juveniles and A for adults; Interaction types: HS for Heterotypic Schooling and PM for Protective Mimicry.

\begin{tabular}{|c|c|c|c|c|c|}
\hline Species & Family & $\mathrm{N}$ & Life phase & Interaction types & Species involved \\
\hline Lutjanus alexandrei & Lutjanidae & 20 & $\mathrm{~J} / \mathrm{A}$ & HS & All of the Haemulon species analyzed \\
\hline Pseudupeneus maculatus & Mullidae & 19 & $\mathrm{~J} / \mathrm{A}$ & HS & H. aurolineatum and $H$. parra \\
\hline Anisotremus virginicus & Haemulidae & 13 & A & HS & All of the Haemulon species analyzed \\
\hline Mulloidichthys martinicus & Mullidae & 10 & A & PM & H. aurolineatum and $H$. squamipinna \\
\hline Sparisoma axillare & Scaridae & 7 & $\mathrm{~J}$ & PM & H. parra \\
\hline Carangoides bartholomaei & Carangidae & 6 & $\mathrm{~J}$ & HS & H. aurolineatum and $H$. squamipinna \\
\hline Ocyurus chrysurus & Lutjanidae & 6 & $\mathrm{~J}$ & HS & H. aurolineatum \\
\hline Harengula clupeola & Clupeidae & 5 & A & PM & H. aurolineatum and H. squamipinna \\
\hline Scarus trispinosus & Scaridae & 5 & $\mathrm{~J} / \mathrm{A}$ & HS & All of the Haemulon species analyzed \\
\hline Scarus zelindae & Scaridae & 3 & $\mathrm{~J} / \mathrm{A}$ & HS & All of the Haemulon species analyzed \\
\hline Lutjanus jocu & Lutjanidae & 2 & $\mathrm{~J}$ & HS & H. parra and H. squamipinna \\
\hline Eucinostomus lefroyi & Gerreidae & 1 & $\mathrm{~J} / \mathrm{A}$ & HS & H. aurolineatum and $H$. squamipinna \\
\hline Chromis multilineata & Pomacentridae & 1 & $\mathrm{~J} / \mathrm{A}$ & HS & $H$. aurolineatum and $H$. squamipinna \\
\hline Anisotremus moricandi & Haemulidae & 1 & A & HS & All of the Haemulon species analyzed \\
\hline
\end{tabular}




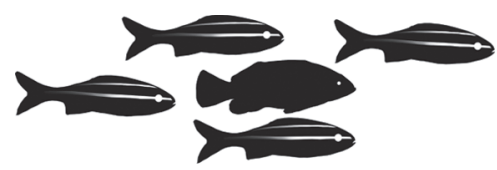

Heterotypic Schooling

- Numerical advantage over predation - None or less morphological or color similarities between species

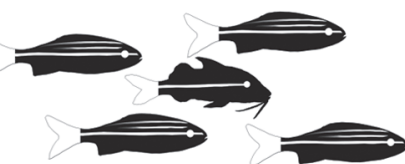

Protective mimicry

- Numerical advantage over predation - Great morphological or color similarities between species

Fig. 1. Schematic diagram presenting differences among the behavioral tactics registered for species joining Haemulon spp. schools.

this behavior to an attendant species. These similarities may enhance the protection for both nuclear and attendant species, once the overall resemblance reinforces numerical and colorrelated advantages over predation (Fig. 3).
Mulloidichthys martinicus, Sparisoma axillare, and Harengula clupeola were observed displaying protective mimicry behaviors with the Haemulon species studied. On these occasions, individuals of these species approached and mixed with schools of other species in order to camouflage themselves, thereby obtaining protection from the large numbers of surrounding fish through the visual confusion of their predators (Fig. 3). In cases of agonistic interactions or attacks by predators, these species rapidly approached a school of Haemulon spp. and adopted similar stances, thus mixing with the main species forming the school. The clupeid Harengula clupeola was the only species found mimicking and feeding in the water column associated with schools of Haemulon parra and Haemulon aurolineatum, being all species involved seen during their juvenile phase (Table 1, Fig. 3). These herrings ( $\sim 5 \mathrm{~cm} \mathrm{TL}$ ) joined them by taking positions similar to the grunts, usually in the middle or in the front portion of the school.

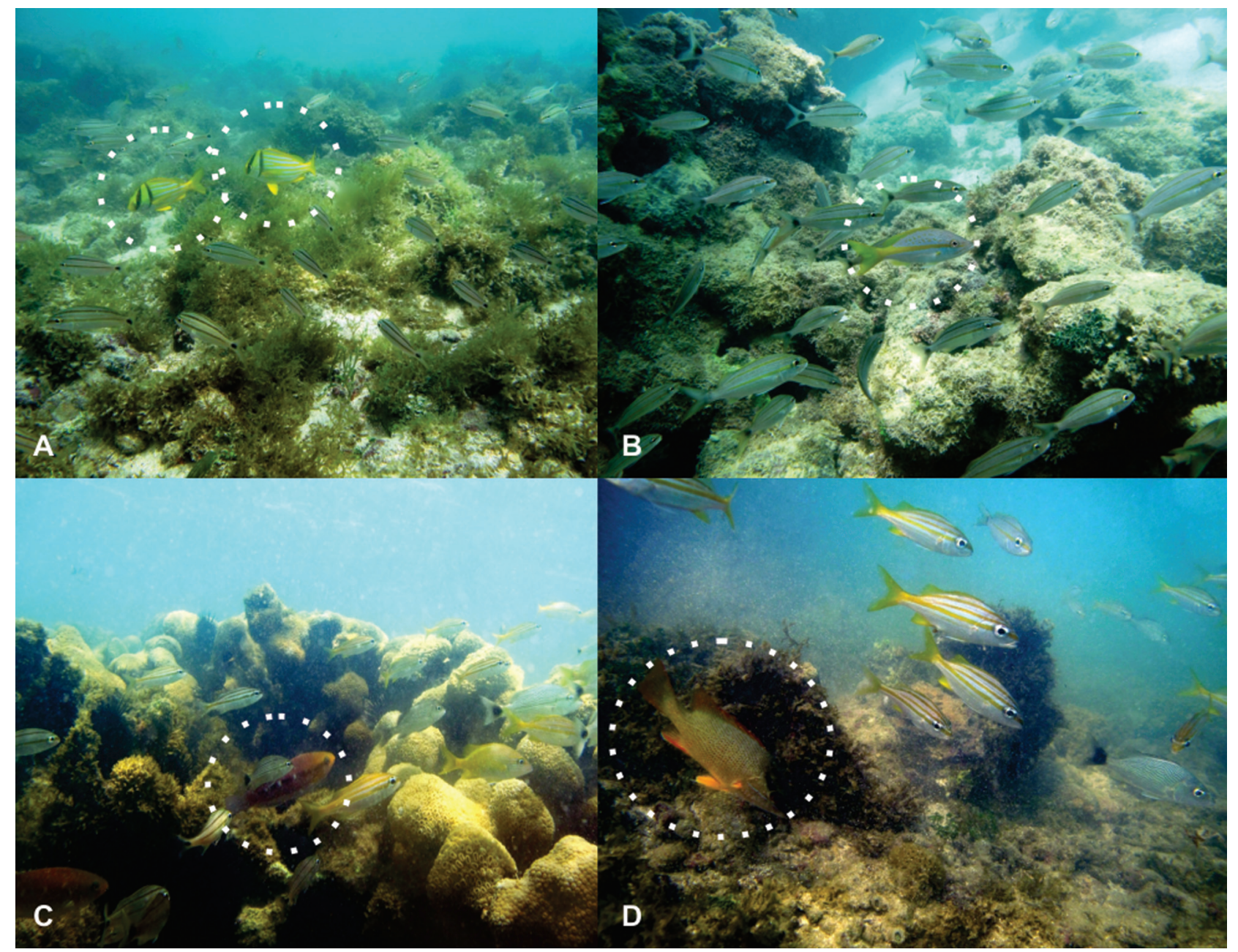

Fig. 2. Heterotypic schooling involving the genus Haemulon and other coral reef fish species. A) Anisotremus virginicus with school of adult H. aurolineatum; B) Ocyurus chrysurus with adult H. aurolineatum and H. squamipinna; C) Scarus zelindae with adult H. parra, H. plumieri and H. squamipinna; D) Lutjanus jocu with adult $H$. parra and H. squamipinna. Circles highlight the non-Haemulon species. Photos: P. H. C. Pereira 


\section{Discussion}

Heterotypic schooling behavior events have been observed among species of the genus Haemulon in the Caribbean, and reported primarily for Haemulon flavolineatum and H. plumieri (Ehrlich \& Ehrlich, 1973; Ogden \& Ehrlich, 1977). Mixed schools are noted for herbivorous species, but they involved only individuals of this feeding guild, composed mostly of individuals of families Scaridae and Acanthuridae (Reinthal \& Lewis, 1986; Lawson et al., 1999; Morgan \& Kramer, 2004).
The formation of mixed schools is directly related to the necessity of maintaining schools with individuals of the same size. If a single species does not have the abundance necessary to satisfy this condition, it often joins schools of other species (Ogden \& Ehrlich, 1977). This situation explains the significant presence of other species in $H$. aurolineatum schools, as this was one of the most abundant species in the study area. In the present study, the necessity for joining an existing school was observed with the herbivores Scarus zelindae and $S$. trispinosus. In spite of the obvious discrepancies of morphological characteristics with Haemulon

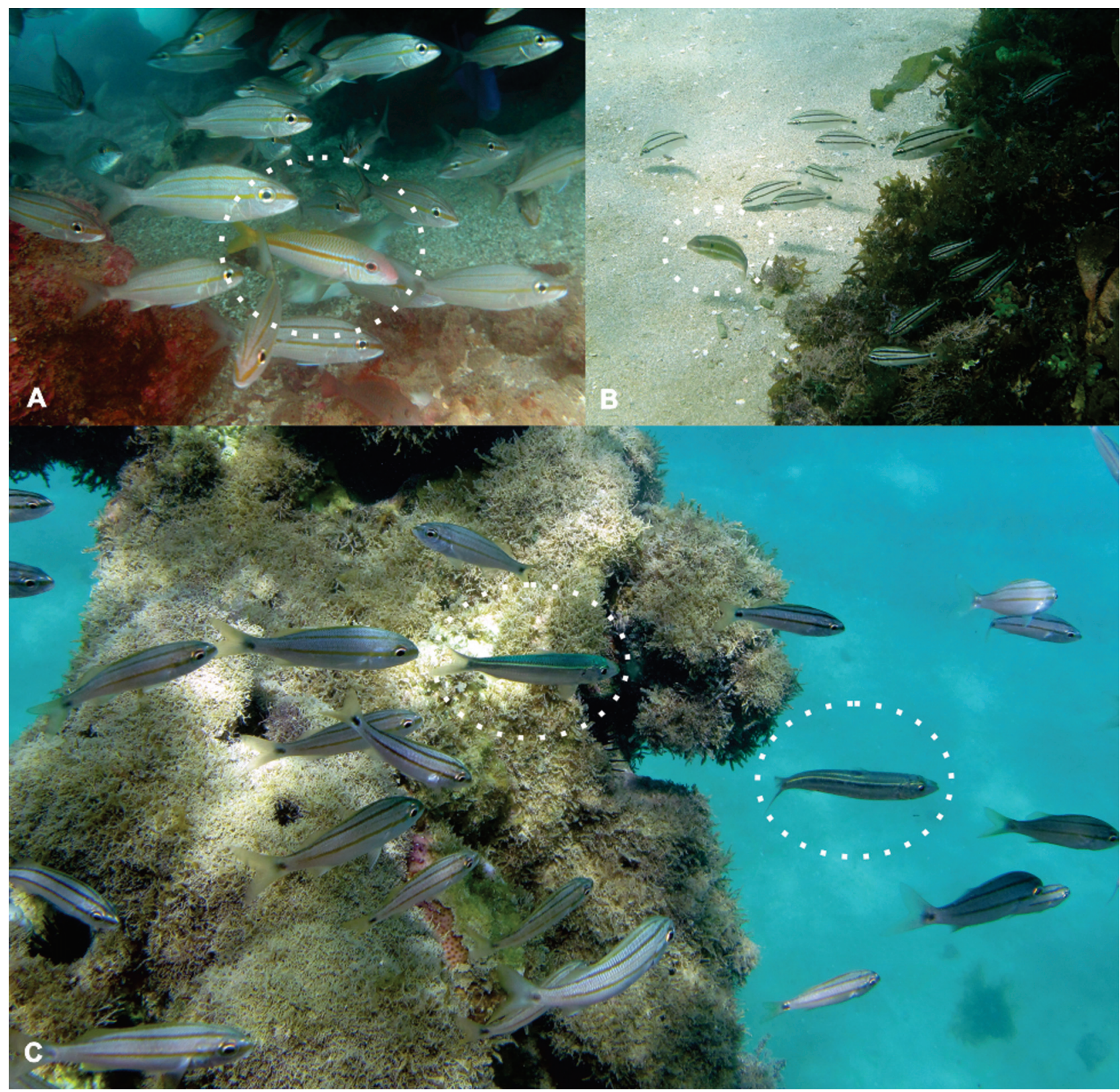

Fig. 3. Protective mimicry between select reef fish species and the genus Haemulon. A) Mulloidichthys martinicus with a school of adult $H$. aurolineatum; B) Sparisoma axillare with $H$. parra juveniles; C) Harengula clupeola with a school of juvenile H. aurolineatum. Circles highlight non-Haemulon species. Photos: P. H. C. Pereira 
spp., they were still found aggregated in mixed schools. Parrotfishes have been targeted by spear and line fishing for many years, resulting in evident decreases in their populations (Ferreira \& Gonçalves, 1999; Mumby, 2006). In addition, Scarus trispinosus is an endemic species from the Brazilian coast, which has a population decline in several localities, with a reduction of up to $50 \%$ in the last 20 or 30 years (Francini-Filho \& Moura, 2008), and was recently included on the IUCN red list as Endangered (Ferreira et al., 2008).

Moland et al. (2005) highlighted two aspects for reporting cases of protective mimicry: the resemblance and formation of heterotypic school between the species and its putative model, and the sharing of the same food source. In the case of the association of Harengula clupeola with Haemulon aurolineatum and H. squamipinna, both conditions were evidenced, as this species closely resembles these grunts, and feeds mainly on copepods, crustacean larvae, and diatoms (Ortaz et al., 1996; Chaves \& Vendel, 2008), demonstrating great diet similarities with the plankton-feeding Haemulon juveniles (Estrada, 1986; Pereira \& Ferreira in prep.).

Krajewski et al. (2004) studied protective mimicry involving $H$. chrysargyreum and the goatfish Mulloidichthys martinicus and suggested that the observed interactions might occur among other striped Haemulon species, which was confirmed by the present study, reporting this type of behavior involving M. martinicus with Haemulon aurolineatum and $H$. squamipinna, both examples of striped grunts. This goatfish was also sighted in association with Haemulon flavolineatum and $H$. plumieri near the Virgin Islands in the Caribbean (Ogden \& Ehrlich, 1977).

Haemulon spp. schools were used by several reef fish species, regardless of phylogenetic and feeding affinities between individuals of other species and those of Haemulon. These heterotypic associations assured protection from potential predators for the attendant species, these facts emphasize the great ecological and social importance of schools of grunts on reef fish communities, especially with the increasing impacts from fisheries on coral reefs.

\section{Acknowledgements}

We would like to thank E. Moland, J. R. Leite and L. Chaves for reviewing and improving the manuscript; D. V. Medeiros for his help with the fieldwork and CAPES for financial support.

\section{Literature Cited}

Altmann, J. 1974. Observational study of behaviour: sampling methods. Behaviour, 49: 227-265.

Brotto, D. S., W. Krohling, I. R. Zalmon. 2007. Comparative evaluation of fish assemblages census on an artificial reef. Revista Brasileira de Zoologia, 24: 1157-1162.

Camazine, S, J. L. Deneubourg, N. R. Franks, J. Sneyd, G. Theraulaz, \& E. Bonabeau. 2003. Self-Organization in Biological Systems. Princeton University Press, 538p.
Chaves, P. T. \& A. L. Vendel. 2008. Análise comparativa da alimentação de peixes (Teleostei) entre ambientes de marisma e de manguezal num estuário do sul do Brasil (Baía de Guaratuba, Paraná). Revista Brasileira de Zoologia, 25: 10-15.

Dafni, J. \& A. Diamant. 1984. School-oriented mimicry, a new type of mimicry in fishes. Marine Ecology Progress Series, 20: 45-50.

Debrot, A. O. \& A. A. Myrberg, Jr. 1988. Intraspecific avoidance as a proximate cause for mixed-species shoaling by juveniles of western Atlantic surgeonfish, Acanthurus bahianus. Bulletin of Marine Science, 43: 104-106.

Ehrlich, P. R. \& A. H. Ehrlich. 1973. Coevolution: Heterotypic schooling in Caribbean reef fishes. American Naturalist, 107: 157-160.

Estrada, R. M. 1986. Hábitos alimentarios de los peces del genero Haemulon (Piscis: Haemulidae) de los arrecifes de La región de Santa Marta, Colombia. Anais Instituto de Investigación Marina, 15: 49-66.

Ferreira, B. P., F. Cava \& M. Maida. 2001. Composição da Pescaria Recifal Observada na Área de Proteção Ambiental Costa dos Corais, Tamandaré - PE - Brasil. Pp. 234-237. In: Congresso Latino Americano de Ciências do Mar, COLACMAR, San Andrés, Colômbia, 15p.

Ferreira, C. E. L., S. R. Floeter, J. L. Gasparini, J. C. Joyeux \& B. P. Ferreira. 2004. Trophic structure patterns of Brazilian reef fishes: a latitudinal comparison. Journal of Biogeography, 31 : 1093-1106.

Ferreira, B. P., S. R. Floeter, L. A. Rocha, C. E. L. Ferreira, R. FranciniFilho, R. Moura, L. Gaspar \& C. Feitosa. 2008. Scarus trispinosus. In: IUCN 2010. IUCN Red List of Threatened Species. Version 2010.4. Available from: http://www.iucnredlist.org/ (access:18 January 2011).

Ferreira, C. E. L. \& J. E. A. Gonçalves. 1999. The unique Abrolhos reef formation (Brazil): need for specific management strategies. Coral Reefs, 18: 352.

Francini-Filho, R. B. \& R. L. Moura. 2008. Dynamics of fish assemblages on coral reefs subjected to different management regimes in the Abrolhos Bank, eastern Brazil. Aquatic Conservation: Marine and Freshwater Ecosystems, 18: 11661179.

Itzkowitz, M. 1977. Social dynamics of mixed-species groups of Jamaican reef fishes. Behavioral Ecology and Sociobiology, 2: 361-384.

Krajewski J. P., R. M. Bonaldo, C. Sazima \& I. Sazima. 2004. The association of the goatfish Mulloidichthys martinicus with the grunt Haemulon chrysargyreum: an example of protective mimicry. Biota Neotropica, 4: 1-4.

Lawson, G. L., D. L. Kramer \& W. Hunte. 1999. Size-related habitat use and schooling behavior in two species of surgeonfish (Acanthurus bahianus and A. coeruleus) on a fringing reef in Barbados, West Indies. Environmental Biology of Fishes, 54: 19-33.

Lindeman, K. C. \& C. Toxey. 2002. Haemulidae. Pp. 1522-1550. In: Carpenter, K. E. (Ed.), FAO Species Identification Guide for Fishery Purposes. The Living Marine Resources of the Western Central Atlantic. Food and Agriculture Organization of the United Nations, Rome.

Maida, M. \& B. P. Ferreira. 1997. Coral Reefs of Brazil: an overview and field guide. Proceedings of the $8^{\text {th }}$ International Coral Reef Symposium, 1: 263-274.

Malcolm, S. B. 1990. Mimicry: status of a classical evolutionary paradigm. Trends in Ecology and Evolution, 5: 57-62. 
Mateo, I. \& W. J. Tobias. 2001. Distribution of shallow water coral reef fishes on the Northeast Coast of St. Croix, USVI. Caribbean Journal of Science, 37: 210-226.

Moland, E., J. V. Eagle \& G. P. Jones. 2005. Ecology and evolution of mimicry in coral reef fishes. Oceanography and Marine Biology, 43: 455-482.

Moland, E. \& G. P. Jones. 2004. Experimental confirmation of aggressive mimicry by a coral reef fish. Oecologia, 140: 676-683.

Morgan, I. E. \& Kramer, D. L. 2004. The social organization of adult blue tangs (Acanthurus coeruleus) on a fringing reef, Barbados, West Indies. Environmental Biology of Fishes, 71: 261-273.

Mumby, P. J. 2006. The impact of exploiting grazers (Scaridae) on the dynamics of Caribbean coral reefs. Journal of Applied Ecology, 16: 747-769.

Nelson, J. S. 2006. Fishes of the world. New York, J. Wiley \& Sons, $4^{\text {th }}$ ed., $601 p$.

Ogden, J. C. \& P. R. Ehrlich. 1977. The behaviour of heterotypic resting schools of juvenile grunts (Pomadasydae). Marine Biology, 42: 273-280.

Ortaz, M., M. E. Rocha \& J. M. Posada. 1996. Food habits of the sympatric fishes Harengula humeralis and H. clupeola (Clupeidae) in the Archipélago de Los Roques National Park, Venezuela. Caribbean Journal of Science, 32: 26-32.

Parrish, J. K. \& L. Edelstein-Keshet. 1999. Complexity, pattern, and evolutionary trade-offs in animal aggregation. Science, 284: 99-101.
Randall, J. E. 2005. A review of mimicry in marine fishes. Zoological Studies, 44: 299-328.

Reinthal, P. N. \& S. M. Lewis. 1986. Social behaviour, foraging efficiency and habitat utilization in a group of tropical herbivorous fish. Animal Behaviour, 34: 1687-1693.

Rocha, L. A, K. C. Lindeman, C. R. Rocha \& H. A. Lessios. 2008. Historical biogeography and speciation in the reef fish genus Haemulon (Teleostei: Haemulidae). Molecular Phylogenetics and Evolution, 48: 918-928.

Rocha, L. A. \& I. L. Rosa. 1999. New species of Haemulon (Teleostei: Haemulidae) from the northeastern Brazilian coast. Copeia 1999: 447-452.

Sazima, I. 2002a. Juvenile grunt (Haemulidae) mimicking a venomous leatherjacket (Carangidae), with a summary of Batesian mimicry in marine fishes. Journal of Ichthyology \& Aquatic Biology, 6: 61-68.

Sazima, I. 2002b. Juvenile snooks (Centropomidae) as mimics of mojarras (Gerreidae), with a review of aggressive mimicry in fishes. Environmental Biology of Fishes, 65: 37-45.

Snyder, D. B., J. E. Randall \& S. W. Michael. 2001. Aggressive mimicry by the juvenile of the redmouth grouper, Aethaloperca rogaa (Serranidae). Cybium, 25: 227-232.

Ward, A. J. W., S. Axford \& J. Krause. 2002 Mixed-species shoaling in fish: the sensory mechanisms and costs of shoal choice. Behavioral Ecology and Sociobiology, 52: 182-187.

Submitted February 7, 2011

Accepted July 17, 2011

Published December 26, 2011 